\title{
PENGELOLAAN SUMBERDAYA ARKEOLOGI UNTUK PARIWISATA BERKELANJUTAN \\ (Pengembangan Wisata Benteng di Pulau Ambon)
}

\author{
Syahruddin Mansyur
}

\section{Abstrak}

Pemerintah Pusat melalui Departemen Kebudayaan dan Pariwisata telab menetapkan tabun 2008 sebagai "Visit Indonesian Year". Salab satu potensi wisata yang dapat dikembangkan untuk mendukung program ini adalah wisata arkeologi khususnya wisata benteng yang jumlabnya cukup banyak dan tersebar dihampir seluruh pulau di Maluku. Wisata benteng di Maluku yang saat ini masih mengandalkan benteng sebagai satu-satunya daya tarik menunjuk.kan belum optimalnya Pemerintah Daerah mengembangkan wisata ini. Salah satu upaya yang perlu dilakukan adalah dengan mengemas berbagai atraksi wisata sebagai tambahan daya tarik bagi wisatawan yang akan berkunjung. Makalah ini mencoba memaparkan prospek wisata benteng di Pulau Ambon dengan menawarkan langkah-langkah yang perlu dilakukan dalam upaya pengembangan wisata yang lebih optimal.

Keyword: Sumberdaya Arkeologi, Pengelolaan, Wisata Benteng, Pariwisata Berkelanjutan.

\section{Pendahuluan}

Sangat disayangkan konflik sosial yang terjadi di Maluku tahun 1999 hingga 2004 serta berbagai insiden lain yang terjadi di dalam negeri berdampak besar bagi kepariwisataan Indonesia khususnya di Maluku. Dampak terbesar yang ditimbulkan adalah tidak adanya rasa aman bagi wisatawan yang datang berkunjung. Namun, perlahan tapi pasti minat wisatawan untuk datang ke Indonesia mulai meningkat. Pemerintah Pusat melalui Departemen Kebudayaan dan Pariwisata terus melakukan upaya untuk mengembalikan citra kepariwisataan Indonesia. Program terkini adalah ditetapkannya tahun 2008 sebagai "Visit Indonesian Year". Jika menoleh ke belakang, program ini sepertinya ingin meneruskan program 
yang sama tahun 1991. Namun, secara makro, program ini tidak hanya bertujuan mengembalikan citra kepariwisataan Indonesia yang sempat terpuruk beberapa tahun belakangan ini. Dampak ekonomi global membuat pemerintah lebih kreatif mengoptimalkan semua sumberdaya termasuk sumberdaya budaya untuk meningkatkan devisa negara, upaya ini tentunya tetap berpedoman pada pengelolaan sumberdaya budaya. Program ini sekaligus merupakan rangkaian program pemerintah yang telah meletakkan pariwisata sebagai sektor penting dalam pembangunan sosial budaya sebagaimana tertuang dalam "Program Pembangunan Nasional 2000-2004" (Tim Pokja Kajian Ekowisata, Puslitbang BP. Budpar: 2003).

Sebelumnya, Pemerintah Pusat telah mencanangkan konsep Pariwisata Berkelanjutan sebagai dasar pengembangan kepariwisataan dalam skala nasional. Konsep Pariwisata Berkelanjutan seperti didefinisikan dalam Piagam Pariwisata Berkelanjutan” (1995), berbunyi pengembangan pariwisata didasarkan pada kriteria keberlanjutan yang secara ekologis harus dikelola dalam jangka panjang dengan tetap memperhatikan aspek ekonomi, etika dan sosial masyarakat (Tim Pokja Kajian Ekowisata, Puslitbang BP. Budpar: 2003). Konsep pariwisata berkelanjutan seperti didefinisikan di atas tampaknya menitikberatkan pada aspek sosial serta terpeliharanya kesinambungan generasi kini hingga generasi mendatang. Dilain pihak, pemerintah daerah diharapkan mampu mengimplementasikan program tersebut dengan melakukan pengembangan wisata sesuai dengan potensi daerahnya. Sejalan dengan itu, Balai Arkeologi Ambon sebagai instansi penelitian bidang kebudayaan, memandang peran penting sumberdaya budaya khususnya yang tanggible (terutama benda-benda budaya) sebagai potensi wisata yang patut dikedepankan. Salah satu yang potensial untuk dikembangkan sebagai salah satu daya tarik wisata adalah wisata benteng.

Pengembangan wisata benteng sendiri bukanlah wacana baru kepariwisataan di Maluku. Setidaknya, upaya ini telah dimulai sejak 1990an oleh pemerintah dengan adanya proyek pemugaran beberapa benteng di daerah ini. Benteng-benteng tersebut kemudian menjadi objek wisata unggulan di beberapa daerah. Benteng Victoria dan Benteng Amsterdam di Pulau Ambon, Benteng Duurstede di Pulau Saparua serta Benteng Belgica di Pulau Banda telah dikenal masyarakat sebagai primadona wisata di daerah ini. Sebaran benteng yang ada serta latar belakang sejarah yang dimilikinya, disadari menjadi potensi berharga upaya pengembangan tersebut. Di sisi lain, tingginya minat wisatawan untuk mengunjungi - menyaksikan langsung - objek-objek tersebut menjadi potensi tersendiri yang harus "ditangkap" oleh stakeholder pariwisata di daerah ini.

Meski demikian, disadari bahwa wisata benteng yang dikembangkan saat ini masih berjalan sendiri-sendiri, pengemasan objek-objek wisata di daerah ini belum terangkum dalam satu paket wisata. Padahal, seperti diketahui wisatawan yang berkunjung ke suatu daerah tentunya akan memaksimalkan kunjungannya. Dengan kata lain, pribahasa "sekali dayung dua tiga pulau terlampaui" berlaku dalam hal ini. Wisatawan yang datang ke benteng Amsterdam misalnya lebih antusias jika disuguhi atraksi wisata yang lain seperti kegiatan budaya atau mendapat informasi lebih seputar latar belakang sejarah benteng tersebut.

Sejalan dengan konsep pariwisata berkelanjutan yang telah dicanangkan dan penetapan tahun 2008 sebagai "Visit Indonesian Year" Balai Arkeologi Ambon berperan serta dengan mengadakan Diskusi Arkeologi bertema "Pengelolaan Warisan Budaya untuk Pengembangan Pariwisata berbasis Kearifan Lokal". Pemilihan tema pariwisata berkelanjutan dalam makalah ini tidak terlepas dari adanya kesamaan konsep antara pariwisata berkelanjutan dan tema diskusi yaitu titik berat pengembangan pariwisata ke depan terletak pada pemberdayaan masyarakat beserta perangkat pengetahuan yang dimilikinya. Berdasarkan hal tersebut, makalah ini mencoba memberi sumbangan pemikiran dengan berusaha menggambarkan prospek wisata benteng yang nampaknya belum optimal dilakukan oleh Pemerintah Daerah. Dasar pemikiran lain, sebagai instansi dibawah naungan Departemen Kebudayaan dan Pariwisata Balai Arkeologi Ambon dituntut memberi dukungan kepada Pemerintah Daerah dalam mengembangkan Kebudayaan dan Kepariwisataan di daerah ini. Upaya tersebut tidak lepas dari pengetahuan ke-arkeologian yang dimilikinya, salah satunya adalah konsep Pengelolaan Sumberdaya Arkeologi perlu diimplementasikan dalam upaya pengembangan pariwisata di Maluku.

\section{Pengelolaan Sumberdaya Arkeologi} berikut:

Pengertian pengelolaan sumberdaya arkeologi dapat diurai sebagai 
- pengelolaan yaitu proses penggunaan sumberdaya secara efektif untuk mencapai sasaran atau pengaturan tentang proses pelestarian, pemanfaatan, serta pendayagunaan sumberdaya;

- sumberdaya merupakan faktor produksi serta bahan dan keadaan yang dapat digunakan manusia untuk memenuhi kebutuhannya, istilah sumberdaya dikenal luas sekitar tahun 1970-an sebagai bagian dari gerakan konservasi (Tanudirdjo, 2006);

- dalam konteks ini, arkeologi dapat diartikan sebagai salah satu wujud kebudayaan yang berkaitan dengan benda-benda hasil karya manusia.

Dengan demikian, pengelolaan sumberdaya arkeologi dapat diartikan sebagai proses penggunaan atau pemanfaatan benda-benda budaya secara bijak dan efektif untuk mencapai sasaran pembangunan. Sebagai bagian dari gerakan konservasi lingkungan, pengelolaan sumberdaya arkeologi bertujuan melestarikan keberadaan benda-benda budaya sebagai sumberdaya yang bermanfaat terus-menerus bagi generasi mendatang. Munculnya kesadaran akan pentingnya pengelolaan sumberdaya arkeologi itu sendiri karena dianggap memiliki beberapa sifat dasar, yaitu :

$\int$ NON-RENEWABLE / tidak terperbaharui

$\int$ IRREVERSIBLE / tidak dapat diubah

$\int$ FINITE / terbatas

$\int$ FRAGILE / rapuh

$\int$ KONTEKSTUAL / memiliki keterhubungan antara yang satu dengan yang lain (ibid, Atmosudiro, 2006).

Karena itu, pengelolaan dalam hal ini memiliki cakupan yang sangat luas, dimulai dengan tahapan penelitian, peletarian, dan pemanfaatan. Jika istilah pengelolaan bersifat umum, istilah lain yaitu manajemen yang bersifat lebih khusus. Dalam konteks ini, digunakan prinsip-prinsip manajemen dalam mengelola sumberdaya arkeologi. Kelima prinsip kerja tersebut yaitu; membuat perencanaan, menyusun organisasi, menyusun jaringan kerja, melaksanakan kegiatan, dan mengadakan pengawasan. Penerapan prinsip kerja ini tentunya membutuhkan berbagai penyesuaian dengan kondisi dan situasi di negara kita, baik yang menyangkut, kelembagaan, sumberdaya manusia, masyarakat, lingkungan dan faktor-faktor lainnya (Suantika,
Syahruddin Mansyur, Pengelolaan Sumberdaya Arkeologi Untuk Pariwisata Berkelanjutan....

2006: 49). Pemerintah sebagai regulator telah membentuk unit-unit kerja yang mengurus bidang arkeologi baik di tingkat pusat maupun daerah. Lembaga-lembaga tersebut yaitu; Pusat Penelitian dan Pengembangan Arkeologi Nasional, Balai Arkeologi di daerah sebagai lembaga penelitian; dan Balai Pelestarian Peninggalan Purbakala sebagai lembaga pelestarian. Adapun lembaga-lembaga yang dapat memanfaatkan sumberdaya arkeologi diantaranya lembaga-lembaga pemerintah seperti Museum, Pemerintah Daerah melalui Dinas Pariwisata. Dan, universitas sebagai lembaga pendidikan yang mengajarkan ilmu arkeologi. Pihak lain yang tidak kalah pentingnya adalah masyarakat.

Di tingkat lokal, lembaga yang terlibat dalam pengelolaan sumberdaya arkeologi hanya ada pada Balai Arkeologi Ambon, Museum Siwalima, Subdin Musjarla Dinas Pendidikan Provinsi Maluku, dan Dinas Pariwisata. Keempat lembaga ini bekerja sesuai dengan Tupoksi masingmasing, Balar Ambon sebagai lembaga penelitian, Subdin Musjarla dan Dinas Pariwisata untuk saat ini sebagai lembaga Pelestarian serta Museum Siwalima dan Dinas Pariwisata sebagai lembaga yang memanfaatkan sumberdaya arkeologi. Belum adanya Balai Pelestarian dan Peninggalan Purbakala di daerah ini sehingga tupoksi pelestarian saat ini ditangani oleh Subdin Musjarla dan Dinas Pariwisata. Namun, kedua lembaga yang berada dibawah naungan Pemerintah Daerah ini, memiliki tenaga ahli arkeologi yang sangat minim (Dinas Pariwisata bahkan tidak memiliki tenaga teknis dengan latar belakang arkeologi). Sehingga, kadangkala dalam melakukan pekerjaan ke-arkeologian mulai dari merencanakan dan melaksanakan penelitian arkeologi, hingga pemugaran, tanpa metode dan sistem yang jelas, sehingga hasilnya bukan melestarikan sumberdaya arkeologi yang ada, malah merusak atau menghilangkan data sejarah budaya yang dikandungnya (Ibid:55). Demikian halnya dengan lembaga non pemerintah termasuk komunitas-komunitas masyarakat yang secara khusus terlibat langsung dalam upaya pengelolaan sumberdaya arkeologi masih sangat kurang.

Dewasa ini, peran masyarakat dalam upaya pengelolaan sumberdaya arkeologi tidak hanya bersifat pasif. Masyarakat sebagai pemilik sumberdaya arkeologi "telah dan harus terlibat dan dilibatkan" dalam setiap tahapan pengelolaan sumberdaya arkeologi. Hal ini mengandung pengertian bahwa di beberapa daerah, masyarakat "telah terlibat" secara mandiri dan 
"dilibatkan" oleh pemerintah maupun lembaga-lembaga non pemerintah dalam pengelolaan sumberdaya arkeologi. Pengertian selanjutnya, "di daerah yang belum" saatnya bagi masyarakat "harus terlibat" secara mandiri, dan waktunya bagi lembaga pemerintah maupun non pemerintah mengajak masyarakat untuk "dilibatkan" dalam pengelolaan sumberdaya arkeologi. Sehingga dengan pengertian tersebut, masyarakat lebih aktif dalam upaya pengelolaan sumberdaya arkeologi.

Sebagai bagian dari gerakan konservasi, pengelolaan sumberdaya arkeologi banyak mengadaptasi konsep pengelolaan lingkungan dengan melakukan pemberdayaan masyarakat lokal secara langsung. Strategi atau pendekatan yang sering digunakan adalah pendekatan partisipatoris diantaranya dengan metode Participatory Rural Appraisal (PR A), Participatory Action Research (PAR), dan Focus Group Discussion (FGD) (Prasodjo, 2004; Sulistyanto, 2006). Ketiga metode tersebut pada dasarnya bertujuan menemukan solusi yang tepat permasalahan-permasalahan yang muncul di tengah masyarakat. Dengan jalan menyatukan tiap pendapat yang datang dari masyarakat itu sendiri diharapkan metode ini dapat memberikan solusi yang dapat diterima semua pihak. Dalam hal pengelolaan sumberdaya arkeologi, permasalahan yang dapat diajukan adalah bagaimana melestarikan sumberdaya arkeologi yang berbasis pada masyarakat itu sendiri. Hal-hal apa yang dapat dilakukan oleh masyarakat berdasarkan pengetahuan kultural yang mereka miliki. Dan berkaitan dengan pengembangan pariwisata adalah bagaimana peran serta masyarakat sebagai tuan rumah. Lebih penting lagi adalah bagaimana meningkatkan kesejahteraan mereka dengan adanya pengembangan pariwisata di daerah mereka.

Peran serta masyarakat dalam pengelolaan sumberdaya arkeologi harus dilakukan sedini mungkin atau sejak tahap perencanaan, pelaksanaan, dan evaluasi. Pengelolaan sumberdaya arkeologi harus memberikan manfaat dan keuntungan ekonomi kepada masyarakat setempat. Selain itu, bahwa pengelolaan sumberdaya arkeologi tersebut harus dilakukan secara berkelanjutan, bukan saja untuk generasi sekarang, tetapi juga untuk generasi mendatang (Ardika, 2002 dalam Mahaviranata, 2005). Ketiga hal inilah yang menjadi prioritas utama dalam upaya pengelolaan sumberdaya arkeologi. Seperti halnya disebutkan oleh Tanudirdjo (2006), dengan mengutip Dicken and Hill dalam Mayer-Oakes (1990), bahwa prinsip dasar manajemen sumberdaya budaya adalah :

1. Kita harus melestarikan sumberdaya budaya jika kita ingin mengambil manfaat darinya,

2. Kita harus mempelajarinya jika ingin memahami manfaat yang kita peroleh,

3. Kita harus menerjemahkan pengetahuan yang kita peroleh untuk masyarakat.

Berpijak pada prinsip dasar tersebut Tanudirdjo (2006), menyimpulkan bahwa proses ini berawal dari masyarakat dan kepada merekalah semua itu harus diserahkan. Dengan menjadikan masyarakat sebagai prioritas utama dapat menghindari konflik kepentingan dalam upaya pemanfaatan sumberdaya arkeologi terlebih untuk pengembangan pariwisata.

\section{Prospek Pengembangan Wisata Benteng di Pulau Ambon \\ - Hasil Inventarisasi Benteng}

Secara keseluruhan, hasil inventarisasi terakhir yang dilakukan oleh PDA bekerjasama dengan Balai Arkeologi Ambon dalam Proyek Inventarisasi Benteng Kolonial, terdapat ... benteng yang tersebar di tiap pulau di Propinsi Maluku. Sebagian besar benteng-benteng tersebut berada di Pulau Ambon, Kepulauan Lease, Kepulauan Banda, dan pulau-pulau lain di Maluku. Selain benteng dengan tembok keliling, beberapa diataranya adalah perbentengan yang merupakan peninggalan masa Perang Dunia II.

Di Pulau Ambon sendiri terdapat 10 titik yang diduga sebagai lokasi benteng. Berdasarkan survei, lokasi-lokasi tersebut masih memperlihatkan sisa-sisa struktur benteng baik dalam keadaan utuh, setengah utuh maupun sisa struktur bahkan ada yang hanya toponim saja. Metode survei dilakukan dengan mengecek titik lokasi benteng berdasarkan peta buatan Belanda. 


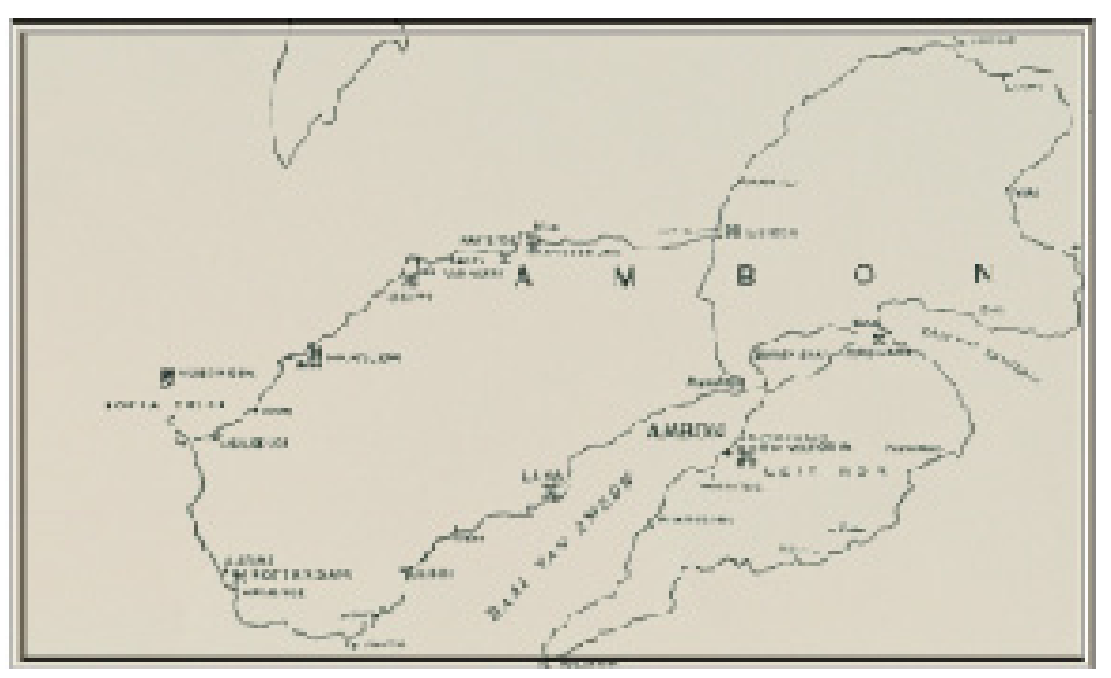

\section{Benteng Nieuw Victoria}

Merupakan benteng yang menjadi cikal bakal Kota Ambon, dibangun pertamakali oleh Portugis pada 1575 dengan nama "Nuestra Senhora da Annunciada". Benteng ini dibangun saat Portugis meninggalkan Ternate karena terusir oleh Sultan Baabullah. Pada tahun 1605, benteng ini kemudian direbut oleh Belanda dan mengganti namanya menjadi Victoria yang berarti "kemenangan". Benteng kemudian mengalami kehancuran akibat gempa dan selesai dipugar pada 1754. Karena perubahan besar-besaran pada fisik bangunan, nama benteng sekaligus diganti menjadi Nieuw Victoria.

Berdasarkan sketsa buatan Belanda, denah dasar benteng berbentuk segi empat dan diperkuat lagi dengan dinding tembok disekeliling benteng. Terdapat dua pintu masuk, bagian depan mengarah ke laut dan bagian belakang mengarah ke darat. Saat ini benteng berada di tengah kota dan menjadi landmark Kota Ambon. Bersebelahan dengan lapangan Merdeka dan Kantor Gubernur dibagian tenggara, terminal Mardika dibagian timur laut, dan Ambon Plaza di bagian barat laut. Kondisi saat ini, dinding benteng hanya tersisa pada bagian barat laut dimana terdapat gerbang utama yang mengarah ke laut, dinding barat daya dan dinding timur laut. Dinding tenggara tidak tampak lagi, hanya terdapat pintu masuk dan sebuah patung yang merupakan bangunan baru yang dibangun oleh
TNI AD. Agak sulit mengidentifikasi bangunan turutan yang ada dalam benteng. Menurut informasi petugas jaga, bangunan turutan yang tersisa hanya gudang senjata pada bagian barat laut dan sebuah bangunan yang kemungkinan difungsikan sebagai aula pada bagian bastion utara, selain itu pada bagian atas bastion utara terdapat sebuah makam Eropa. Sebagian besar bangunan yang ada saat ini merupakan bangunan baru yang dibangun oleh TNI AD, diantaranya pos jaga, kantor, tempat beribadah dan kompleks perumahan anggota TNI. Benteng ini berada dibawah penguasaan TNI AD dan menjadi kompleks militer.

Benteng Nieuw Victoria memiliki nilai sejarah sangat penting, selain menjadi cikal bakal kota Ambon dimana segala aktifitas pemerintahanperdagangan dipusatkan pada awal penguasaan Belanda. Benteng Victoria juga menjadi tempat pelaksanaan hukuman gantung bagi mereka yang menentang Belanda pada saat itu. Tidak sedikit pejuang-pejuang Maluku berakhir perjuangannya di benteng ini, diantaranya Kapitan Pattimura dan Kapitan Ulupaha. Saat ini, lokasi tempat pelaksanaan hukuman gantung yaitu di depan benteng Victoria dibangun patung Pattimura sebagai tugu peringatan. Sayangnya, di lokasi tersebut tidak jauh dari patung Pattimura sedang dibangun Merdeka Square.

\section{Benteng Middelburg}

Benteng ini berada di Kelurahan Passo, Kecamatan Baguala dan masuk ke dalam wilayah administratif Kota Ambon. Lokasi benteng berada di belakang pertigaan ruas jalan raya yang menghubungkan Passo-Natsepa dan Passo-Laha. Saat ini benteng berada di tengah-tengah pemukiman penduduk, harus melewati halaman rumah jika hendak menuju ke benteng baik dari arah depan maupun belakang, sehingga sulit melihat sisa benteng dari arah jalan raya.

Kondisi benteng telah rusak berat, sisa struktur yang ada hanya dua sisi dinding setinggi \pm 5 meter yaitu dinding timur dan barat, pada dinding timur terdapat 3 buah jendela. Dinding utara dan selatan hanya tersisa bagian pondasi saja. Denah dasar benteng adalah segi empat, ukuran bagian dalam $\pm 5 \times 5$ meter, dinding benteng tersusun dari bahan batu bata tanpa dilapisi plester dengan ketebalan $\pm 50 \mathrm{~cm}$. Dari sisa struktur yang ada memperlihatkan bentuk bangunan yang sama dengan benteng Amsterdam di Hila vaitu berupa "blokbuis". 
Titik lokasi benteng berada pada daratan sempit yang diapit oleh teluk Binnen dan teluk Baguala. Menurut informasi, benteng ini menjadi pusat pengawasan aktifitas yang menghubungkan dua wilayah pada masa tersebut yaitu Leihitu dan Leitimur, berdasarkan pengamatan peta terbitan Belanda, kedua teluk dihubungkan oleh kanal yang sekaligus menjadi akses menuju benteng (Pers.Com, Bonke:2008). Sekarang ini kanal tersebut masih ada dan berada di sisi jalan yang menghubungkan Passo-Natsepa meski yang tersisa sudah tidak menghubungkan kedua teluk. Pengamatan gambar juga memperlihatkan bahwa dulunya lokasi benteng berada dekat dengan garis pantai dan saat ini karena proses pengendapan, garis pantai kini berjarak 100 meter dari lokasi benteng.

\section{Benteng (Kota) Laha}

Benteng ini hanya tersisa nama saja, berdasarkan pengamatan di lokasi yaitu di Desa Laha (belakang Bandara Pattimura) tidak ditemukan sisa struktur. Saat ini, penduduk memberi nama sebuah jalan yang lokasinya dekat pantai dengan nama Jalan Benteng Kota Laha. Menurut mereka, di lokasi tersebut dulu pernah berdiri sebuah benteng. Namun, agak sulit menemukan sisa struktur di lokasi tersebut yang ada hanya dua sisa struktur yang diduga sebagai gerbang karena mengapit jalan, meski dari bahan batu karang namun tidak memperlihatkan sisa kapur sebagai bahan spesi. Di loksai ini juga ditemukan veilbox peninggalan Jepang.

Beberapa hal menjadi catatan mengenai benteng ini adalah:

1. Berdasarkan peta buatan Belanda, terdapat titik lokasi benteng yang saat ini dikenal sebagai Desa Laha. Namun, peta ini masih perlu diperiksa lebih lanjut apakah peta tersebut dibuat berdasarkan situasi yang ada pada saat itu atau peta ini dibuat sebagai sebuah rencana pendirian titik perbentengan di Pulau Ambon oleh Belanda. Dalam hal ini, kasus di Semarang menjadi sebuah contoh, berdasarkan peta buatan Belanda di Kota Lama Semarang terdapat sebuah benteng yaitu Benteng Vijfhoek yang diduga menjadi cikal bakal Kota Semarang. Namun, penelitian arkeologis tidak menunjukkan sisa struktur sehingga peta tersebut diduga sebagai peta yang menggambarkan rencana (gambar pra rencana) Belanda (Purwanto, 2005:33).
2. Sumber sejarah menyebutkan bahwa Benteng Kota Laha adalah nama lain dari benteng "Nuestra Senhora da Annunciada" yang dibangun oleh Portugis pada tahun 1575. Jika demikian halnya, maka benteng ini mengacu ke Benteng Victoria yang ada di Kota Ambon.

3. Berdasarkan kedua pernyataan di atas maka benteng Kota Laha tidak pernah dibangun baik Portugis maupun Belanda di Desa Laha.

4. Namun, jika peta tersebut menggambarkan situasi pada saat itu, boleh jadi sebuah benteng pernah berdiri di lokasi dimaksud tetapi memiliki nama berbeda. Selain itu, informasi masyarakat tentang keberadaan sebuah benteng di lokasi tersebut tentunya tidak boleh dikesampingkan. Beberapa kasus di Maluku dan Maluku Utara memberi informasi bahwa penghancuran benteng sering dilakukan oleh masyarakat sekitar dengan mempreteli material benteng.

\section{Benteng Rotterdam}

Benteng ini berada di Desa Larike Kecamatan Leihitu Kabupaten Maluku Tengah. Jika dilihat pada peta pulau Ambon, benteng ini berada di ujung barat Jazirah Leihitu. Lokasi benteng berada pada arah timur laut sekitar \pm 10 meter dari tepi pantai dan disebelah barat benteng mengalir sungai Larike. Saat ini benteng berada di tengah-tengah pemukiman penduduk. Kondisi benteng tinggal puing dengan tiga titik sisa struktur dinding yang terpisah cukup jauh. Sisa struktur yang agak utuh berada di sebelah timur tidak jauh dari sungai. Berdasarkan hasil wawancara, masyarakat setempat meyakini bahwa benteng dibangun oleh Portugis dan dibangun kembali oleh Belanda pada tahun 1670 dan diberi nama Amsterdam. Nama Amsterdam kemudian dipindahkan untuk nama benteng di Desa Hila sedang di Larike diberi nama baru yaitu Rotterdam.

Berdasarkan hasil pengamatan di lapangan menunjukkan beberapa hal, yaitu:

1. Titik sisa struktur yang terpisah cukup jauh memperlihatkan bahwa benteng ini berukuran cukup besar. 
2. Sungai yang mengalir di sebelah barat sisa struktur benteng dimanfaatkan sebagai akses yang menghubungkan laut menuju benteng.

3. Titik lokasi benteng yang berada di ujung barat jazirah Leihitu menunjukkan bahwa fungsi pertahanan benteng Rotterdam pada masanya sangat vital karena menjadi benteng pertahanan awal Belanda menghadapi serangan musuh yang hendak masuk ke teluk Ambon yang datang dari arah barat. Asumsi ini diperkuat lagi jika memperhatikan ukuran benteng yang cukup besar.

\section{Benteng Storm (Vlissingen)}

Benteng Storm berada di Pulau Ureng (Kepulauan Tiga) Desa Ureng Kecamatan Leihitu Kabupaten Maluku Tengah. Benteng berada di sebuah pulau kecil, dan lokasinya berada di atas sebuah perbukitan di bagian timur pulau. Denah dasar benteng berbentuk segitiga dengan panjang tiap sisi \pm 5 meter. Pulau Ureng adalah pulau terluar dari tiga gugusan pulau di sebelah barat laut Pulau Ambon, posisi ini menjadi tempat ideal untuk pengamatan ke daerah sekitarnya (termasuk sisi barat Tanjung Sial/ Huamual Belakang - pada masanya, daerah tersebut menjadi pusat Kerajaan Huamual). Sehingga, benteng ini diduga sebagai pos pengamatan Belanda pada masa Perang Huamual.

\section{Benteng Haarlem}

Seperti umumnya benteng yang ada di wilayah ini, Benteng Haarlem berada tidak jauh dari pantai. Lokasi benteng cukup mudah dijangkau karena berada di tengah pemukiman penduduk. Benteng relatif utuh dan masih menampakkan bentuk aslinya yaitu sebuah blokhuis berdenah dasar persegi empat dengan ruangan tambahan yang menempel pada bentuk blokhuis di sisi kiri dan kanan. Bentuk bangunan ini menjadikan benteng terbagi atas tiga ruangan utama yaitu ruang tengah berukuran lebih besar dan ruang yang lebih kecil menempel di sisi kiri dan sisi kanan, ruangan inipun masing-masing terbagi dua pada tiap sisinya. Dinding bangunan ini hanya memiliki setengah dari ketinggian bangunan utama, bagian atasnya terdapat beberapa lekukan yang merupakan bekas balok-balok penyangga atap. Pintu masuk berada pada dinding benteng yang menghadap ke arah tenggara (darat), dan pada bagian atas pintu terdapat prasasti benteng. Bagian tulisan yang dapat terbaca pada prasasti yaitu "BLOKHUIS VAN DER CAPELLEN GEBOUWDA 1817 DEN 8 DECEMBER .........". Pada bagian atas setiap sisi dinding terdapat lubang bekas jendela, sedang bagian bawahnya terdapat lubang lebih kecil yang merupakan lubang angin. Bagian dalam blokhuis juga terdapat lubang-lubang untuk menempatkan balok penyangga papan.

\section{Benteng Ceith (Benteng Van Verre ?)}

Saat ini benteng Ceith hanya tinggal puing saja, meski demikian jejak-jejak yang tertinggal masih dapat diidentifikasi sebagai bekas pondasi dinding benteng. Jejak-jejak yang menampakkan bekas struktur benteng yaitu sisa-sisa material benteng yang terdiri dari susunan bata merah dengan adanya spesi. Masyarakat setempat pun sangat meyakini di lokasi tersebut pernah berdiri sebuah benteng yang menyerupai benteng Amsterdam di Hila. Penduduk sekitar menyebut lokasi ini dengan sebutan "Kota", lokasi ini sendiri berada di pinggir pantai dan telah menjadi sebuah pemukiman. Beberapa rumah bahkan menjadikan pondasi benteng yang telah diratakan sebagai lantai teras rumah, dan material benteng yaitu batuan cadas yang berbentuk persegi digunakan sebagai anak tangga. Berdasarkan informasi penduduk, tidak diketahui tentang latar sejarah benteng ini baik nama, tahun pembangunan maupun informasi lainyya, mereka hanya mengetahui bahwa benteng ini dibangun oleh Belanda.

Berdasarkan hasil penelusuran dengan mengkomparasikan informasi penduduk dan sumber-sumber sejarah yang ada, benteng yang ada di Desa Seith bisa dikaitkan dengan benteng Van Verre.

Informasi penduduk baik di Hila maupun Keitetu sebagaimana lokasi keberadaan benteng Van Verre menurut peta yang ada mereka tidak pernah mengetahui keberadaan benteng Van Verre di kedua desa tersebut. Informasi tambahan menyebutkan bahwa Benteng Van Verre adalah nama lain dari benteng Amsterdam yang ada di Hila. Tanpa mengesampingkan informasi yang diperoleh dari penduduk tentang nama Van Verre yang adalah nama lain benteng Amsterdam. Berdasarkan penulusuran sumbersumber sejarah, diperoleh informasi bahwa Benteng Van Verre adalah benteng pertama yang dibangun oleh Belanda di pulau Ambon sebelum 
benteng Amsterdam. Benteng ini dibangun di Desa Seith dengan nama "Compaign Van Verre".

\section{Benteng Amsterdam}

Benteng Amsterdam adalah objek wisata favorit di daerah ini yang terletak di Desa Hila. Secara administratif masuk dalam wilayah Kecamatan Leihitu Kabupaten Maluku Tengah. Wilayah yang sering disebut dengan Jazirah Leihitu ini berada di Pulau Ambon, tepatnya di bagian utara Pulau Ambon yang berhadapat langsung dengan Tanjung Sial (P. Seram). Sebagai objek wisata favorit, benteng ini telah mengalami beberapa kali pemugaran, pertamakali pada tahun 1991 oleh Departemen Pendidikan dan Kebudayaan. Kemudian, pada tahun 1997 dipugar oleh Kanwil Dikbud Propinsi Maluku. Pemugaran terakhir dilakukan oleh Dinas Pariwisata pada tahun 2006.

Seperti yang tertera pada prasasti pemugaran yang dilakukan oleh Kanwil Dikbud Propinsi Maluku, benteng ini dibangun oleh Gerard Demmer pada tahun 1642, dan diperluas oleh Arnold De Vlaming Van Duds Hoorn pada tahun 1649 hingga 1656. Benteng ini adalah benteng kedua yang dibangun oleh Belanda di wilayah ini. Benteng ini berperan sangat penting bagi Belanda dalam usahanya merebut dominasi atas Kepulauan Rempah-Rempah dari bangsa Portugis. Benteng ini merupakan pusat militer Belanda pada waktu itu melawan Portugis yang berpusat di benteng Victoria yang dulunya bernama "Nuestra Senhora da Annunciada".

Bangunan berupa Blokhuis dengan denah dasar berbentuk segi empat yang diperkuat dengan tembok keliling. Bagian dalam tembok keliling terdapat tiga bastion yang mengarah ke laut, ketiga bastion ini dihubungkan oleh sebuah jalan intai yang bermula dari pintu masuk. Bagian dalam dinding terdapat sebuah sumur yang terletak di depan pintu masuk benteng. Bangunan blokhuis memiliki satu pintu masuk, dari luar terdapat dua buah lubang angin yang berada di atas pintu dan lebih keatas lagi terdapat lubang yang lebih besar sebagai tempat menempatkan meriam. Lubang-lubang yang sama juga tampak pada keempat sisi dinding blokhuis dengan posisi sejajar. Demikian halnya pada bagian atas terdapat dua lekukan meriam pada tiap sisi dinding. Secara umum, bagian dalam blokhuis terbagi atas tiga lantai.
Catatan sejarah juga menyebutkan bahwa di benteng inilah GE Rumphius menulis beberapa artikel selama keberadaannya di Maluku mengamati kehidupan botanika di daerah ini. Ahli botanika ini juga terkenal sebagai orang yang pertamakali menyebut tentang keberadaan artefak neolitik di wilayah ini.

\section{Benteng Leiden}

Benteng Leiden berada di Desa Hitu Lama, saat ini lokasi benteng telah menjadi daerah pemukiman dan struktur benteng yang tersisa hanya pondasi saja. Oleh masyarakat, pondasi benteng kini telah dimanfaatkan sebagai pondasi rumah tinggal. Sisa pondasi yang ada menampakkan batu karang sebagai bahan utama dengan menggunakan spesi campuran pasir dan kapur sebagai perekat. Menurut informasi Bapak Muhammad Pelu pemilik rumah tersebut menyebutkan bahwa bagian belakang rumah yang ada saat ini mengikuti pondasi benteng yang ada. Oleh penduduk sekitar, kapur yang ada pada pondasi benteng sering diambil sebagai bahan campuran untuk membuat sirih-pinang. Berdasarkan gambar benteng (berangka tahun 1650) koleksi Bapak Pelu yang diperoleh dari seorang wisatawan Belanda yang pernah berkunjung ke Desa Hitu Lama, memperlihatkan bentuk bangunan berupa blokhuis dengan tembok keliling. 
Hasil Inventarisasi Benteng Kolonial di Pulau Ambon

\begin{tabular}{|c|c|c|c|}
\hline No & Nama Benteng & Kondisi Benteng & Posisi Astronomis \\
\hline \multicolumn{4}{|c|}{ Kota Ambon } \\
\hline 1 & Nieuw Victoria & $\begin{array}{l}\text { Sudah direnovasi (difungsikan } \\
\text { sebagai kompleks } \\
\text { militer/infanteri) }\end{array}$ & $50341^{\prime} 29.06^{\prime \prime}$ \\
\hline \multirow[t]{2}{*}{2} & \multirow[t]{2}{*}{ Middelburg } & \multirow[t]{2}{*}{ Hampir utuh } & $503^{\circ} 37.863^{\prime}$ \\
\hline & & & E $128^{\circ} 15.231^{\prime}$ \\
\hline 3 & (Kota) Laha & $\begin{array}{l}\text { Tidak ditemukan sisa struktur } \\
\text { (Saat ini menjadi toponim untuk } \\
\text { daerah sekitamya) }\end{array}$ & \\
\hline \multicolumn{4}{|c|}{ Maluku Tengah } \\
\hline \multirow[t]{2}{*}{1} & \multirow[t]{2}{*}{ Rotterdam } & \multirow[t]{2}{*}{ Hampir utuh } & $503^{\circ} 44.976^{\prime}$ \\
\hline & & & E $128^{\circ} 55.595^{\prime}$ \\
\hline \multirow[t]{2}{*}{2} & \multirow[t]{2}{*}{ Strorm (Vlissingen) } & \multirow[t]{2}{*}{ Hampir utuh } & $503^{\circ} 38.932^{\prime}$ \\
\hline & & & E $127^{\circ} 54.657$ \\
\hline \multirow[t]{2}{*}{3} & \multirow[t]{2}{*}{ Haarlem } & \multirow[t]{2}{*}{ Hampir utuh } & $503^{\circ} 38.494^{\prime}$ \\
\hline & & & E $127^{\circ} 58.047^{\prime}$ \\
\hline \multirow[t]{2}{*}{4} & \multirow[t]{2}{*}{ Ceith } & \multirow[t]{2}{*}{ Tinggal puing } & $503^{\circ} 35.483^{\prime}$ \\
\hline & & & E $128^{\circ} 01.737^{\prime}$ \\
\hline 5 & Van Verre & $\begin{array}{l}\text { Tidak ditemukan (nama lain dari } \\
\text { Amsterdam - ? atau nama lain } \\
\text { benteng Ceith - ?) }\end{array}$ & \\
\hline \multirow[t]{2}{*}{6} & \multirow[t]{2}{*}{ Amsterdam } & \multirow[t]{2}{*}{ Sudah direnovasi total } & $503^{0} 34.953^{\circ}$ \\
\hline & & & E $128^{\circ} 05.002^{\prime}$ \\
\hline 7 & Leiden & $\begin{array}{l}\text { Tinggal pondasi (digunakan } \\
\text { sebagai pondasi numah) }\end{array}$ & $\begin{array}{l}\mathrm{S} 03^{\circ} 35.053^{\prime} \\
\text { E } 128^{\circ} 10.574^{\prime}\end{array}$ \\
\hline
\end{tabular}

\section{Prinsip-Prinsip Pengembangan}

Agar dapat menetapkan prinsip-prinsip pengembangan wisata benteng di Maluku, maka perlu mengindentifikasi permasalahan yang ada. Permasalahan-permasalahan yang ada berkaitan dengan beberapa pertanyaan diantaranya:

1. Bagaimana kondisi fisik bangunan benteng yang ada di Pulau Ambon sebagai wilayah sebaran benteng yang akan dijadikan sebagai destinasi wisata

2. Sejauhmana peranan benteng-benteng yang ada di wilayah ini bagi Belanda pada masanya sebagai upaya pendugaan nilai penting dari segi nilai sejarahnya

3. Bagaimana kehidupan sosial masyarakat sekitar bangunan benteng tersebut

4. Bagaimana anggapan masyarakat terhadap benteng yang ada di lingkungan mereka

5. Bagaimana perilaku masyarakat menjaga kondisi bangunan benteng yang ada di lingkungannnya

Jawaban dari pertanyaan-pertanyaan tersebut akan mengarah pada dua agenda penting dalam upaya pengembangan wisata benteng yaitu menyangkut fisik bangunan benteng itu sendiri dan agenda sosiologis menyangkut peran serta masyarakat dalam upaya pelestarian. Jika mengacu pada pengelolaan sumberdaya budaya, keduanya tidak boleh dikesampingkan dan harus dilaksanakan secara menyeluruh. Pertanyaan mendasar selanjutnya adalah bagaimana kondisi wilayah tersebut sebagai destinasi wisata secara keseluruhan. Konteks pertanyaan di atas dimaksudkan untuk menjawab pertanyaan Bisakah mewnijudkan wisata benteng di wilayah ini ?. Pengemasan yang baik dengan memadukan berbagai jenis wisata adalah sesuatu yang dapat dijual sebagai daya tarik wisata. Dalam artian bahwa pengemasan beberapa atraksi wisata dalam satu paket wisata harus dijadikan perhatian utama agar dapat mendatangkan banyak wisatawan.

Sebelum melakukan pemanfaatan sumberdaya arkeologi untuk tujuan pariwisata, harus dilakukan kajian yang mengacu pada Manajemen Sumberdaya Arkeologi. Berkaitan dengan Manajemen Sumberdaya Arkeologi ini, Tanudirdjo (2006) menyebutkan kajian tersebut harus melakukan: 
1. Identifikasi,

2. Pendugaan nilai penting,

3. Pendugaan dampak, dan

4. Mitigasi.

Sebagai rangkuman cara kerja di atas, berikut ini adalah agenda penting dalam upaya pengembangan wisata benteng. Agenda ini tentunya lebih terfokus pada hal-hal yang berkaitan dengan pengelolaan sumberdaya budaya. Agenda penting tersebut, yaitu:

1.Agenda menyangkut fisik bangunan a.Inventarisasi

Dalam hal ini dilakukan pendataan secara keseluruhan termasuk didalamnya bahan, teknologi, arsitektur bangunan dan lingkungan sekitarnya. Inventarisasi yang telah dilakukan oleh PDA dalam proyek inventarisasi benteng kolonial di Maluku dapat dijadikan acuan awal. Selanjutnya, untuk memperoleh data yang konfrehensif dibutuhkan semacam studi tekhnis atau studi kelayakan. Sebagai upaya yang bertujuan untuk melestarikan sumberdaya arkeologi maka data penting lainnya adalah kondisikondisi tertentu yang akan mengakibatkan kerusakan pada fisik bangunan baik faktor alam maupun manusia. Data penting berkaitan dengan faktor alam dapat berupa kondisi iklim dan cuaca. Sedang, faktor manusia dapat berupa perilaku-perilaku masyarakat yang dapat berakibat langsung maupun tidak langsung terhadap kerusakan bangunan. Penelusuran tentang sejarah yang melatarbelakangi pendirian benteng penting dilakukan untuk melakukan pendugaan nilai penting.

b. Konservasi

Konservasi dalam hal ini diartikan sebagai upaya yang dilakukan dengan tujuan pemeliharaan yang bersifat khusus agar dapat mempertahankan kondisi benteng sesuai dengan konsep awalnya. Sementara yang harus diperhatikan adalah sejarah, budaya atau nilai-nilai tradisional, fungsi sosial dan ekonomi, iklim dan lokasi geografisnya. Dengan tujuan tersebut konservasi arkeologi memiliki tugas pokok yaitu maintenance/pemeliharaan, preservation/ pengawetan, restoration/pemugaran, reconstruction/rekonstruksi dan adaptation/penyesuaian (Danisworo, 1997: 18-19). Selain tugas pokok yang bersifat teknis, konservasi arkeologi harus pula didukung dengan menyertakan regulasi pendirian bangunan baru, penggantian, dan pemugaran. Hal ini sebagai upaya untuk mencegah terjadinya perubahan desain, bahan dan setting bangunan yang akan dilestarikan (Tanudirdjo, 2004).

Berdasarkan hasil pendataan terakhir, diperoleh gambaran tentang kondisi terkini benteng-benteng yang ada di wilayah ini. Benteng yang masih tersisa diantaranya Rotterdam dengan kondisi hampir punah, Haarlem dengan kondisi hampir utuh, Amsterdam yang telah dipugar, Middelburg dengan kondisi hampir punah dan Nieuw Victoria yang saat ini difungsikan sebagai kompleks militer. Sedang benteng lain berdasarkan peta Belanda, saat ini hanya dapat diketahui lokasinya saja. Berkaitan dengan upaya konservasi yang bersifat teknis tentunya harus memperhatikan kondisi benteng yang ada.

c. Revitalisasi

Upaya ini bertujuan untuk menampilkan kembali fisik bangunan maupun setting yang masih mungkin ditampilkan dengan tujuan memberikan kenyamanan bagi wisatawan. Benteng yang tidak dapat di pugar lagi, cukup dengan mendirikan pusat informasi mengenai latar belakang sejarah benteng. Sebagai daya tarik pendukung, ditambahkan dengan menampilkan atraksi wisata lain di sekitar lokasi benteng. Atraksi wisata yang ditampilkan dapat berupa wisata alam maupun yang berkenaan dengan aktifitas masyarakat.

2.Agenda sosiologis menyangkut peran serta masyarakat

a. Agenda Sosiologis untuk Pelestarian

Sikap tidak peduli terhadap sumberdaya arkeologi disebabkan adanya kesenjangan historis, sehingga kehadirannya tidak bermakna bagi masyarakat setempat (Mahmud, 1998:19). Anggapan seperti inilah yang ada ditengah masyarakat tentang keberadaan benteng di lingkungan mereka. Lebih parah lagi bahwa 
benteng adalah produk bangsa penjajah yang tidak memberikan manfaat bagi mereka. Hal ini merupakan persoalan yang harus dipecahkan dengan melakukan pendekatan sosiologis.

Kesadaran akan pentingya peran serta masyarakat dalam upaya pelestarian sumberdaya arkeologi karena pendekatan hukum belum bisa efektif menyelesaikan persoalan sumberdaya arkeologi. Berbagai kasus pengrusakan bahkan penghancuran sumberdaya arkeologi memberikan bukti bahwa payung hukum yang ada yaitu UU BCB No. 5 Tahun 1992 belum mampu memberi kesadaran kepada para pelakunya. Oleh karena itu, hubungan sosiologis yang memperkuat eksistensi di masa lalu perlu dibangun kembali (Ibid:21). Disinilah peran penting pemerintah, mampu membangkitkan kesadaran masyarakat tentang perlunya melestarikan sumberdaya arkeologi yang mereka miliki.

\section{b. Agenda Sosiologis untuk Pengembangan Wisata}

Ada dua hal yang perlu dilakukan berkaitan dengan agenda sosiologis sebuah pengembangan wisata yaitu; pertama, mengikutsertakan masyarakat sebagai bagian atraksi wisata. Sebagai sebuah wisata budaya, hal ini tentunya menjadi keharusan mengingat daya tarik yang akan ditawarkan adalah segala sesuatu yang berkaitan dengan kebudayaan setempat. Tidak hanya terbatas pada pertunjukan seni tetapi juga segala sesuatu yang berkaitan dengan adat-istiadat setempat, meliputi; aturan lokal, pakaian, ritual upacara, gaya hidup, dan agama/keyakinan. Akhir-akhir ini, wisatawan mancanegara juga sangat tertarik pada aktifitas seharihari masyarakat. Atraksi budaya spesifik yang dapat dikembangkan adalah kegiatan pengelolaan pada masa petik cengkeh yang ada daerah ini.

Kedua, memberikan kesempatan kepada masyarakat untuk mengembangkan usaha wisata yang bertujuan untuk kesejahteraan mereka. Tidak hanya sekedar memberikan kesempatan kepada masyarakat untuk mengembangkan kreatifitas mereka, akan tetapi harus disertai dengan bimbingan baik berupa pelatihan maupun pendampingan.
Setelah kedua agenda di atas, langkah penting berikutnya adalah melakukan sinkronisasi atraksi wisata. Pemerintah daerah melalui instansi terkait menyusun jadwal kegiatan-kegiatan budaya berdasarkan hasil inventarisasi yang telah dilakukan sebelumnya. Jadwal kegiatan budaya ini harus dirembugkan bersama oleh pemerintah dan masyarakat, peran pemerintah dalam hal ini hanya sebagai fasilitator yang menjembatani keinginan-keinginan masyarakat. Jadwal kegiatan budaya ini kemudian disosialisasikan untuk memberikan pemahaman kepada masyarakat bahwa jadwal seperti ini bertujuan mendatangkan wisatawan lebih banyak. Jadwal ini dimaksudkan agar wisatawan betul-betul merasa puas atas kunjungannya ke daerah ini, mereka yang datang berwisata menyaksikan banyak atraksi wisata. Langkah ini juga dapat dijadikan sebagai upaya awal untuk mendatangkan wisatawan, dengan harapan setelah melihat atraksi wisata yang disajikan mereka bisa datang kembali. Hal ini, sekaligus merupakan salah satu prinsip dasar pariwisata yaitu berupaya menyajikan atraksi wisata yang memungkinkan wisatawan untuk kembali berkunjung ke tempat tersebut. Selain penyajian atraksi wisata yang menarik, hal lain yang perlu diperhatikan adalah; keamanan dan kenyamanan wisatawan, saling menghargai antara wisatawan dan masyarakat setempat selaku tuan rumah, ketersediaan sarana dan prasarana, penyajian informasi hal-hal yang berkaitan dengan kepariwisataan.

Langkah selanjutnya adalah melakukan promosi yang terintegrasi, peran Pemerintah Daerah sekali lagi dibutuhkan bersama dengan pihak swasta (agen-agen wisata) untuk mempromosikannya bersama destinasi wisata lain di daerah ini. adalah:

Beberapa atraksi wisata yang dapat dikembangkan diantaranya

1. Wisata arkeologi dan wisata sejarah, termasuk benteng-benteng tradisional yang dulunya dimanfaatkan sebagai pusat-pusat pertahanan pejuang-pejuang lokal. Untuk menambah daya tariknya, perlu mendirikan pusat informasi atau semacam museum yang menampilkan diorama perjuangan menentang penjajahan di daerah ini. 
2. Wisata budaya berupa upacara-upacara adat seperti upacara pukul sapu di Negeri Morela dan upacara-upacara adat lain yang ada di daerah ini. Kegiatan-kegiatan budaya dapat juga dilaksanakan dalam kompleks benteng sebagai upaya memusatkan kegiatankegiatan tersebut.

3. Wisata alam seperti pembukaan jalur tracking ke bentengbenteng tradisional yang ada di puncak-puncak gunung di daerah ini yaitu Benteng Wawane di Negeri Seith dan Benteng Kapahaha di Negeri Morela. Wisata alam yang memanfaatkan keindahan panorama pantai didaerah ini, dapat juga dengan mengembangan wisata diving.

4. Wisata yang menampilkan aktifitas masyarakat pada waktuwaktu tertentu misalnya masa petik cengkeh. Aktifitas seperti ini tentunya sangat menarik bagi wisatawan mancanegara.

Beberapa keunggulan yang dimiliki dengan adanya pengembangan wisata benteng di Pulau Ambon adalah:

1. Lokasinya yang tidak terlalu jauh jika dibandingkan dengan destinasi wisata lain di daerah ini.

2. Pengemasan paket wisata yang terdiri dari berbagai atraksi wisata diantaranya, wisata arkeologi dan sejarah, wisata alam dan wisata budaya dan tradisi, serta wisata minat khusus. Hal ini tentunya menjadi daya tarik tersendiri yang akan memberi kepuasan bagi wisatawan.

3. Pengembangan wisata benteng di Pulau Ambon memiliki beberapa keunggulan dari sisi nilai penting kesejarahan, diantaranya:

a. Merupakan salah satu bukti awal kedatangan Belanda di wilayah Maluku,

b. Seorang Naturalis terkenal Eropa, George Everhard Rumphius, pernah menetap di Benteng Amsterdam, dan menyelesaikan artikel dari bukunya yang sangat terkenal "Amboinsche Rariteitenkamer".

c. Perbentengan (benteng-benteng Belanda) maupun benteng tradisional yang ada di daerah ini menjadi bukti sejarah perjuangan pejuang-pejuang daerah ini menghadapi bangsa kolonial. Pada masa lalu, daerah ini terkenal dengan perang
Wawane dan Perang Kapahaha. Demikian pentingnya wilayah Maluku bagi daerah-daerah sekitarnya, Kerajaan Gowa-Tallo pada masa itu bahkan mengirim bantuan untuk menghadapi Belanda.

4. Pengembangan wisata benteng di daerah ini sekaligus dapat dijadikan sarana untuk menambah pengetahuan bagi generasi muda tentang latar sejarah yang pernah terjadi di daerah ini. Wisata yang menambah pengetahuan seperti ini ini tentunya lebih menarik lagi dengan menampilkan objek-objek arkeologi yang melatarinya.

\section{Penutup}

Wacana pengembangan wisata benteng bukanlah hal baru bagi dunia kepariwisataan di Maluku. Setidaknya, upaya ini telah diawali dengan melakukan pemugaran, seperti Benteng Amsterdam di Pulau Ambon dan beberapa benteng di wilayah lain. Wacana pemanfaatan sumberdaya arkeologi yang ada di Maluku sebagai objek wisata pun telah sering kal dikemukakan, wacana inipun tidak sekedar mengedepankan pemanfaatan saja, tetapi dibutuhkan penanganan khusus yang sesuai dengan prinsip Manajemen Sumberdaya Arkeologi (Suantika, 2005; Ririmase, 2007 dan Handoko 2007). Benteng yang memiliki peran penting sebagai bukti sejarah bagi generasi mendatang agar tetap sadar dan waspada tidak mengalami hal serupa di masa akan datang; dan kondisi benteng di Maluku yang sangat menyedihkan karena rusak dan tidak terawat menjadi pertimbangan mendasar untuk segera melakukan upaya penanganan yang sesuai dengan prinsip Manajemen Sumberdaya Arkeologi. (Suantika, 2005:14).

Tulisan ini kembali mewacanakan hal serupa dengan lebih fokus pada peninggalan arkeologi berupa benteng yang ada di Pulau Ambon. Disadari bahwa pemanfaatan benteng sebagai objek wisata yang ada di Pulau Ambon belum dilakukan secara maksimal. Benteng hanya berdiri sendiri sebagai satu-satunya objek yang menjadi daya tarik wisatawan. 
Syahruddin Mansyur, Pengelolaan Sumberdaya Arkeologi Untuk Pariwisata Berkelanjutan....

Sebagai penutup, beberapa kesimpulan dapat dikemukakan berikut ini:

1. Sekali lagi, kondisi benteng yang ada di Maluku, khususnya di Pulau Ambon saat ini dalam kondisi tidak terawat, bahkan beberapa diantaranya telah hilang. Padahal di sisi lain, benteng-benteng tersebut menyimpan berbagai cerita sejarah tentang perjuangan para pendahulu menentang penjajahan. Ini tentunya menjadi potensi yang besar jika kita mau mengelola dan memanfaatkan untuk generasi mendatang.

2. Participatory Rural Appraisal (PRA), Participatory Action Research (PAR), dan Focus Group Discussion (FGD), adalah metode pendekatan pemberdayaan masyarakat yang dapat digunakan dalam upaya pelestarian sumberdaya arkeologi.

3. Arah kebijakan pariwisata nasional adalah pariwisata berkelanjutan yang mengedepankan peran serta masyarakat dalam pengelolaan pariwisata. Arah kebijakan ini sejalan dengan pengelolaan sumberdaya arkeologi yang beranggapan masyarakat adalah pemilik sumberdaya arkeologi. Hal paling mendasar tentang pelibatan masyarakat dalam pengelolaan pariwisata adalah pengembangan pariwisata harus mendatangkan manfaat yang sebesar-besarnya bagi kesejahteraan masyarakat lokal.

4. Tata kerja Manajemen Sumberdaya Arkeologi dalam upaya pemanfaatan sumberdaya arkeologi sebagai objek wisata adalah dengan melakukan; Identifikasi, Pendugaan nilai penting, Pendugaan dampak, dan Mitigasi (Manajemen pelaksanaan).

5. Pengemasan paket wisata yang memadukan berbagai jenis wisata diantaranya wisata arkeologi, wisata sejarah, wisata alam, wisata budaya, dan wisata minat khusus adalah langkah yang tepat dalam pengembangan wisata benteng di daerah ini.

6. Dengan pengelolaan yang tepat, tidak mustahil wisata benteng di Pulau Ambon dapat diwujudkan.

Adapun rekomendasi yang perlu disampaikan berkenaan dengan pengembangan wisata benteng ini adalah:

1. Sekali lagi, segera melakukan upaya pelestarian benteng-benteng yang ada di daerah ini. Tentunya dengan penanganan yang tepat sesuai dengan kaidah-kaidah Manajemen Sumberdaya Arkeologi. Tidak kalah pentingnya adalah upaya pelestarian dilakukan dengan
Syahruddin Mansyur, Pengelolaan Sumberdaya Arkeologi Untuk. Pariwisata Berkelanjutan....

pendekatan sosiologis untuk memberikan penyadaran kepada masyarakat pentingnya pelestarian sumberdaya arkeologi..

2. Memprioritaskan pelibatan masyarakat dalam upaya pengelolaan sumberdaya arkeologi. Pelibatan masyarakat dalam upaya ini dilakukan sejak tahap perencanaan, pelaksanaan, dan evaluasi.

3. Melakukan identifikasi secara keseluruhan berkaitan dengan fisik bangunan dan aspek-aspek sosiologis lainnya. Identifikasi ini bertujuan sebagai acuan untuk langkah berikutnya yaitu pendugaan nilai penting, pendugaan dampak, dan mitigasi. Identifikasi ini sekaligus bermanfaat dalam menentukan atraksi wisata lain yang dapat dijadikan sebagai daya tarik pendukung.

4. Pemerintah Daerah harus memberikan payung hukum agar kelangsungan pengelolaan sumberdaya budaya di daerah ini dapat dinikmati oleh generasi mendatang. Olehnya itu, penyusunan Perda tentang pengelolaan sumberdaya budaya harus segera dimulai.

\section{Sebagai bagian akhir dari penutup ini, ilustrasi di bawah ini bisa dijadikan gambaran;}

"Berwisata ke pesisir utara Pulau Ambon anda dapat mengunjungi benteng Amsterdam yang dulunya menjadi pusat pertahanan Belanda dalam usahanya merebut wilayah ini dari tangan Portugis. Di sana terdapat sebuah museum yang menampilkan berbagai informasi tentang sejarah awal kedatangan bangsa Belanda dan menyaksikan diorama perjuangan masyarakat Leihitu dalam mempertahankan wilayahnya. Ternyata, di benteng ini juga dulunya adalah tempat tinggal GE Rumphius seorang Naturalis Eropa yang meneliti tentang kehidupan botanika di Maluku. Informasi tentang keseharian GE Rumphius, tempat-tempat yang dikunjungi dan gambar-gambar yang menampilkan hal-hal menarik yang ditemui selama penelitiannya, ditampilkan pada panel khusus di Museum tersebut. Benteng ini juga menjadi pusat pagelaran budaya, bagi anda yang bermaksud berkunjung ke sini harus memperhatikan jadwal pagelaran budaya yang akan ditampilkan. Kunjungan yang tepat adalah bulan Agustus karena pada waktu tersebut digelar "Festival Budaya Jazirah Leihitu". 
Selain mengunjungi benteng Amsterdam, anda juga bisa mengunjungi benteng lain yaitu Benteng Rotterdam di Negeri Larike, Blokhuis Haarlem di Negeri Lima, dan Benteng Van Verre di Negeri Seith. Meski kondisinya sudah rusak, bahkan ada yang tinggal puing saja keingintahuan anda akan terpuaskan dengan adanya pusat informasi mengenai sejarah benteng. Beberapa gambar dan foto ditampilkan untuk memberikan informasi tentang kondisi dan bentuk bangunan ketika masih difungsikan. Sepanjang perjalanan anda juga bisa menyaksikan kegiatan sehari-hari penduduk sambil menyaksikan panorama keindahan alam disekitarnya dan keramahtamahan penduduk juga bisa anda rasakan ketika berkunjung ke daerah ini. Daerah lain yang harus anda kunjungi adalah Negeri Morela yang setiap 7 Syawal setelah Hari Raya Idul Fitri, masyarakat setempat mengadakan upacara Pukul Sapu. Dan, bagi anda yang hobi melakukan pendakian, dua jalur tracking yaitu jalur menuju benteng Wawane dan jalur menuju benteng Kapahaha adalah tempat menantang yang patut anda coba. Pendakian menuju benteng Wawane dimulai dari Negeri Seith dan jalur menuju benteng Kapahaha dimulai dari Negeri Morela.

Bagi anda yang berniat untuk tinggal beberapa hari, tersedia homestay di beberapa negeri (desa). Selain itu, penginapan dengan fasilitas yang cukup memadai bisa anda dapatkan di Negeri Hila sebagai pusat aktifitas kepariwisataan di daerah ini.

Setelah puas mengunjungi berbagai tempat wisata di daerah ini, anda bisa membawa berbagai ole-ole berupa kerajinan tangan maupun berbagai jenis kue yang ditawarkan cukup murah oleh penduduk setempat."

\section{DAFTAR PUSTAKA}

Atmosudiro, S. 2006 Manajemen Sumberdaya Arkeologi dan Kendala Penerapannya. Yogyakarta: Jurusan Arkeologi Fakultas Ilmu Budaya Universitas Gajah Mada. Disampaikan dalam Pelatihan Pengelolaan Sumberdaya Arkeologi Tingkat Dasar Tahun 2004 di Trowulan. belum diterbitkan

Danisworo, M. 1997 The Meaning of Preservation and Conservation. Dalam Preservation and Conservation of Cultural Heritage in Indonesia. Yogyakarta: Gadjah Mada University Press.

Handoko, W. 2007 Sumberdaya Arkeologi Menuju Industri Pariwisata di Maluku: Masalah, Peluang, Tantangan dan Solusinya. Dalam Kapata Arkeologi. Edisi Khusus Mei 2007 ISSN 1858-4101: 119-139. Ambon: Balai Arkeologi Ambon.

Mahaviranata, P. 2005 Tinggalan Arkeologis, Desa Hu'u sebagai Aset Pengembangan Pariwisata Budaya di Kabupaten Dompu, Nusa Tenggara Barat. Dalam Kumpulan Makalah PIA X-2005 di Yogyakarta. Jakarta: Ikatan Ahli Arkeologi Indonesia. Belum diterbitkan

Mahmud, Irfan. 1998 Pelestarian Benda Cagar Budaya Ditinjau dari Sudut Pandang Sosiologis. Dalam Somba Opu Edisi ke-6 Tahun IV April September 1998: 15-29. Ujung Pandang: Suaka Peninggalan Sejarah dan Purbakala Sulawesi Selatan dan Tenggara.

Prasodjo, T. 2004 Pemberdayaan Masyarakat dalam Pengelolaan Sumberdaya Arkeologi. Disampaikan dalam Pelatihan Pengelolaan Sumberdaya Arkeologi Tingkat Dasar Tahun 2004 di Trowulan. belum diterbitkan

Purwanto. L.M.F. 1997 Kota Kolonial Lama Semarang (Tinjauan Umum Sejarah Perkembangan Arsitektur Kota). Dalam Dimensi Teknik Arsitektur Vol. 33, No. 1 Juli 2005: 27-33. Semarang: Universitas Kristen Petra.

Ririmase M.N.R. 2007 Maluku: Sebuah Citra dalam Bingkai Sumberdaya Arkeologi. Dalam Kapata Arkeologi Edisi Khusus Mei 2007 ISSN 1858-4101: 101-118. Ambon: Balai Arkeologi Ambon. 
Suantika, I Wayan. 2005 Peran dan Fungsi Benteng Masa Kolonial bagi Pembangunan Daerah Maluku. Dalam Kumpulan Makalah PIA X-2005 di Yogyakarta. Jakarta: Ikatan Ahli Arkeologi Indonesia. Belum diterbitkan

.2006 "Penelitian Arkeologi dalam Siklus". Draft tulisan. Ambon: Balai Arkeologi Ambon. belum diterbitkan.

Sulistyanto, B. 2006 Penerapan Metode Focus Group Discussion dalam Penelitian Arkeologi Publik. Dalam Arkeologi: Dari Lapangan ke Permasalahan: 186-196, ISBN 979-5579-7-6. Bandung: Ikatan Ahli Arkeologi Indonesia Komda Jawa Barat.

Tanudirdjo, D.A. 2004 Pengelolaan Sumberdaya Arkeologi : Sebuah Pengantar Yogyakarta: Jurusan Arkeologi Fakultas Ilmu Budaya Universitas Gajah Mada. Bahan Diskusi untuk Pelatihan Pengelolaan Sumberdaya Arkeologi Tingkat Dasar Tahun 2004 di Trowulan. belum diterbitkan

. 2006 Pengantar Pengelolaan Sumberdaya Budaya. Yogyakarta: Jurusan Arkeologi Fakultas Ilmu Budaya Universitas Gajah Mada. Bahan Diskusi untuk Pelatihan Pengelolaan Sumberdaya Arkeologi Tingkat Dasar Tahun 2006 di Yogyakarta. belum diterbitkan

Tim Pokja Kajian Ekowisata, Puslitbang BP. Budpar. 2004 Kajian Kebijakan Pariwisata Berkelanjutan. Jakarta: Departemen Kebudayaan dan Pariwisata. 